\title{
MEMBANGUN AGILITAS ORGANISASI MELALUI BUDAYA ORGANISASI DAN BERBAGI PENGETAHUAN
}

\author{
Sri Raharso \\ Jurusan Administrasi Niaga, Politeknik Negeri Bandung \\ email : harsopolban@gmail.com.
}

\begin{abstract}
ABSTRAK
Lingkungan bisnis terus berubah secara cepat dan tidak pasti. Agar tetap eksis, organisasi perlu memiliki kapabilitas untuk dapat mengeksploitasi perubahan, dikenal sebagai agilitas. Penelitian ini bertujuan untuk mempelajari bagaimana agilitas organisasi dapat dibangun melalui budaya organisasi dan aktivitas berbagi pengetahuan. Data disurvei terhadap 394 partisipan dari tiga organisasi bisnis. Regresi ganda digunakan untuk mengevaluasi model penelitian. Hasil penelitian mengindikasikan budaya organisasi secara signifikan mempengaruhi berbagi pengetahuan, dan secara simultan dengan berbagi pengetahuan secara signifikan berpengaruh terhadap terhadap agilitas organisasi. Potensi penelitian di masa yang akan datang juga dibahas.

Kata kunci: agilitas, budaya organisasi, berbagi pengetahuan
\end{abstract}

\begin{abstract}
Business environment are facing rapid and often uncertainty. Surviving in these turbulent situations will be possible in organization have the essential capabilities, known as agility. This study investigated the relationship between corporate culture, knowledge sharing, and organizational agility. Survey data was collected from 394 respondens from three organization. Multiple regression was used to assess the research model. According to the regression analyses, corporate culture influence on knowledge sharing and whether more leads to organizaitional agility, simultaneously. Potential avenues for further research are explored. Keywords: agility, corporate culture, knowledge sharing
\end{abstract}

\section{PENDAHULUAN}

Setiap organisasi bisnis harus selalu mengantisipasi perubahan lingkungan bisnis yang serba tidak pasti agar tetap kompetitif. Tidak mengherankan apabila Thompson (1967) menyatakan bahwa tugas terpenting dari organisasi adalah mengelola ketidakpastian. Sebab, ketidakpastian telah dikenali sebagai penyebab utama gagalnya organisasi (Small dan Downey, 1996). Sebaliknya, pandangan yang lebih positif dari Drucker (1968) menyatakan bahwa perubahan bukanlah ancaman, tetapi kesempatan bagi organisasi untuk mengeksploitasi lingkungan yang turbulent agar memberikan manfaat atau kesejahteraan bagi organisasi (Almahamid, 2008; Sharifi dan Zhang, 2001; Taghizadeh, 2015).

Mencari cara-cara kreatif untuk merespon perubahan lingkungan dan menghasilkan kesuksesan memerlukan metode dan pendekatan baru (Fahami et al., 2017). Paradigma baru yang mempersepsikan perubahan sebagai kesempatan untuk merespon, mengeksploitasi, dan memperoleh manfaat dikenal sebagai agilitas (Sharifi dan Zhang, 2001; Taghizadeh, 2015). Oleh karena itu, organisasi perlu memiliki kapabilitas untuk merespon dan mengambil manfaat dari perubahan lingkungan yang tidak pasti tersebut. Menurut Zhang dan Sharifi (2000), kapabilitas tersebut adalah: responsiveness, competency, flexibility, dan speed. Jadi, agilitas di abad 21 bukan lagi sebuah pilihan, tetapi merupakan suatu kebutuhan bagi organisasi (Harraf et al., 2015), manufaktur maupun layanan (Fahami et al., 2017).

Resep yang sempurna tidak ada didalam mengembangkan agilitas organisasi (Harraf et al., 2015). Perubahan lingkungan yang kontinyu dan tidak berpola menyebabkan agilitas organisasi bersifat dinamis, harus mengikuti lingkungan bisnis yang turbulent. Artinya, agilitas merupakan proses yang terus berjalan, merupakan suatu "matter of becoming" daripada "being" (Alzoubi et al., 2011). Konsekuensinya, organisasi akan memiliki agilitas yang "tepat" apabila setiap anggota organisasi memiliki pedoman perilaku untuk selalu menjadi agile. Hal ini dapat tercapai apabila budaya organisasi mendukung pada tercapainya agilitas organisasi. Jadi agilitas lebih dari sekedar business proses, harus menjadi karakteristik inti yang wajib dimiliki oleh anggota organisasi, tim, dan seluruh budaya organisasi (Harraf et al., 2015).

Budaya organisasi merupakan pondasi dasar untuk membangun agilitas organisasi. Sebab, 
budaya organisasi mempengaruhi seluruh aspek organisasi, akan memberdayakan organisasi berdasarkan keyakinan dan nilai-nilai bersama, termasuk agilitas (Fahami et al., 2017; Sarshar dan Hezarjaribi, 2016). Perilaku anggota organisasi lebih ditentukan oleh budaya organisasi daripada arahan dari manajemen senior, selain itu implementasi strategi di berbagai organisasi lebih banyak ditentukan oleh budaya organisasi, terlebih ketika strategi tersebut dipersepsikan tidak sejalan dengan budaya organisasi yang ada (Jarnagin dan Slocum, 2007). Budaya organisasi menyediakan konteks intelektual dan sosial yang dibutuhkan untuk memodern-kan proses-proses dalam organisasi, sehingga organisasi menjadi lebih agile (Jafarnejad dan Shahai, 2010). Secara empiris, Fahami et al. (2017) berhasil membuktikan adanya pengaruh yang signifikan dari budaya organisasi terhadap agilitas bank pertanian di Iran. Yazdani dan Salarzahi (2014), Saki dan Amirnejad (2016), serta Sanchuli dan Yazdani (2015) juga mengidentifikasi adanya hubungan yang signifikan antara budaya organisasi dengan agilitas organisasi.

Salah satu model budaya organisasi adalah model competing value framework dari Cameron dan Quinn (2006), yang tergolong dalam model yang secara komprehensif mampu menganalisis budaya organisasi (Rai, 2011); terdiri dari empat tipe budaya, yaitu: clan, adhocracy, market, dan hierarchy. Dalam dunia nyata, sangat jarang sebuah organisasi hanya memiliki satu tipe budaya organisasi; organisasi yang efektif memerlukan kinerja yang paripurna dari empat set kriteria budaya organisasi tersebut. Organisasi yang memiliki empat tipe budaya tersebut dipertimbangkan sebagai "seimbang" dan akan berkinerja tinggi (Yu dan Wu, 2009).

Budaya organisasi di pihak lain telah dipertimbangkan sebagai faktor kritis dalam membangun dan memperkuat kreasi pengetahuan dan manajemen pengetahuan dalam organisasi, yang selanjutnya berdampak terhadap bagaimana anggota organisasi belajar, memperoleh, dan membagikan pengetahuan (Teng, 2010; Alavi dan Leidner, 2001; Gupta dan Govindarajan, 2000). Manajemen pengetahuan merupakan faktor dominan untuk mendapatkan keunggulan kompetitif bagi organisasi (Bhagat et al., 2002), meningkatkan kinerja dan kesuksesan organisasi (Martin, 2000; Nonaka dan Takeuchi, 1995), serta mengaktualisasi human capital (Brown dan Woodland, 1999). Kreasi pengetahuan dan manajemen pengetahuan merupakan pembeda antara organisasi yang sukses dengan yang tidak sukses (Nonaka, 1991).
Inti dari manajemen pengetahuan adalah berbagi pengetahuan atau knowledge sharing (Raharso dan Tjahjawati, 2014; Mason dan Pauleen, 2003; Gupta et al., 2000), yang bermanfaat bagi organisasi untuk menciptakan "value added benefits" (Liebowitz, 2001). Berbagi pengetahuan merupakan pertukaran pengetahuan di antara para individu melalui interaksi sosial (Senge, 1997). Proses berbagi pengetahuan terdiri dari knowledge collecting dan knowledge donating (Hooff dan Ridder, 2004). Dengan demikian, budaya organisasi tidak hanya memiliki relasi dengan agilitas organisasi, tetapi juga dengan manajemen pengetahuan (Rai, 2011), lebih khusus lagi dengan berbagi pengetahuan (Suppiah dan Sandhu, 2011). Rai (2011) menyatakan bahwa budaya organisasi merupakan faktor kritis pembangun dan penguat manajemen pengetahuan dalam organisasi. Secara empiris, Andam (2017) berhasil membuktikan adanya pengaruh yang signifikan dari budaya organisasi terhadap berbagi pengetahuan di organisasi publik di Iran. Penelitian Alattas dan Kang (2015) di perusahaan terbesar di Saudi Arabia juga membuktikan adanya pengaruh yang signifikan dari budaya organisasi terhadap perilaku berbagi pengetahuan. Penelitian terhadap organisasi di Malaysia oleh Suppiah dan Sandhu (2010) menghasilkan temuan akan adanya pengaruh berbagai tipe budaya organisasi terhadap perilaku berbagi pengetahuan. Al-Alawi et al. (2007) juga menyatakan bahwa budaya organisasi memiliki hubungan positif dengan berbagi pengetahuan.

Mengembangkan agilitas organisasi, selain budaya organisasi, dibutuhkan pengetahuan sebagai sumber daya inti (core resource) yang akan ditransformasikan menjadi produk atau layanan (Biao-wen, 2010). Nilai pengetahuan akan bertambah apabila pengetahuan tersebut dibagikan (Quinn et al., 1998), dalam bentuk informasi, ketrampilan, maupun pengalaman, ke rekan kerja maupun anggota tim yang lain (Ersoy dan Mahdy, 2015). Aktivitas berbagi pengetahuan merupakan kunci utama untuk merespon setiap perubahan lingkungan bisnis secara cepat dan proaktif (Almahamid, 2008). Dengan demikian, aktivitas berbagi pengetahuan, yang dipengaruhi oleh budaya organisasi, juga memiliki relasi dengan agilitas organisasi. Hasil tersebut dibuktikan oleh Taghizadeh (2015), yang berhasil mengidentifikasi relasi manajemen pengetahuan dengan agilitas organisasi di perusahaan auto-parts berskala kecil dan besar di Iran. Yaghoubi dan Dahmardeh (2011) juga membuktikan bahwa manajemen pengetahuan merupakan faktor kritis penentu suksesnya agilitas 
organisasi. Terakhir, Mehrabi et al. (2013) juga menyatakan adanya hubungan yang positif antara berbagi pengetahuan dengan agilitas organisasi.

Secara parsial, relasi budaya organisasi dengan berbagi pengetahuan, budaya organisasi dengan agilitas organisasi, dan perilaku berbagi pengetahuan dengan agilitas telah banyak diteliti. Kajian empiris yang mempelajari interaksi antara tiga variabel tersebut secara simultan, terutama dalam konteks Indonesia, masih sangat terbatas. Amirnejad dan Milad (2015) merupakan salah satu peneliti yang telah melakukannya, dengan perilaku berbagi pengetahuan sebagai mediator antara budaya organisasi dengan agilitas organisasi di kantor pusat perusahaan minyak di Iran.

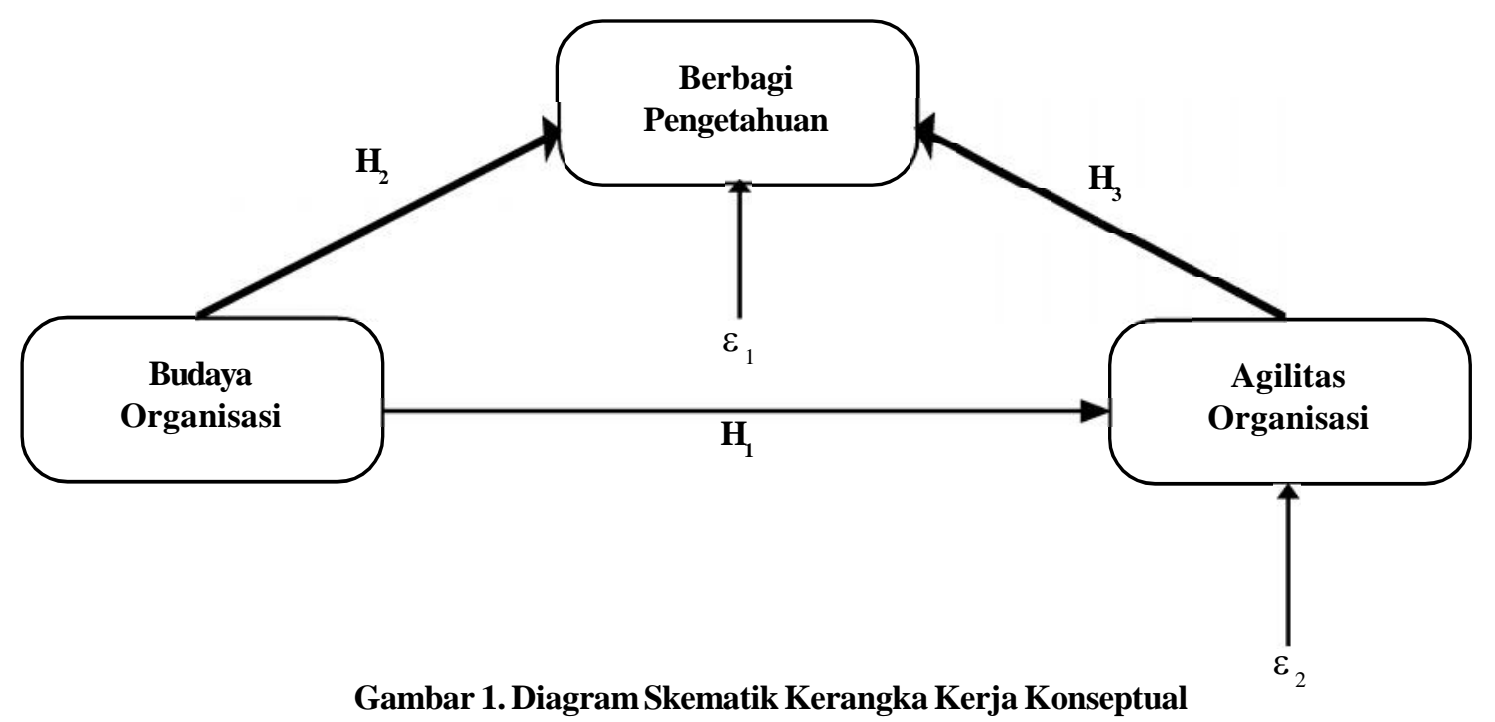

Berdasarkan uraian tersebut, maka rumusan pertama dari penelitian adalah: apakah budaya organisasi memiliki pengaruh terhadap agilitas organisasi $\left(\mathrm{H}_{1}\right)$, merupakan pendorong bagi aktivitas berbagi pengetahuan, maka rumusan kedua dari penelitian ini adalah: apakah budaya organisasi memiliki pengaruh terhadap berbagi pengetahuan $\left(\mathrm{H}_{2}\right)$. Berikutnya, kajian literatur menyatakan bahwa agilitas organisasi memerlukan masukan pengetahuan sebagai sumber daya utama. Oleh karena itu, rumusan masalah ketiga adalah: apakah variabel berbagi pengetahuan memiliki pengaruh terhadap agilitas organisasi $\left(\mathrm{H}_{3}\right)$.

Sejak tahun 1980-an konsep budaya organisasi secara serius telah menjadi perhatian para peneliti dan praktisi (Cameron dan Quinn, 2006; Schein, 2004), karena terbukti merupakan faktor penting pengungkit kinerja organisasi (Jarnagin dan Slocum, 2007; Cameron dan Quinn, 2006). Banyak perdebatan yang terjadi ketika ingin memahami dan mendiagnosis budaya organisasi (Suppiah dan Sandhu, 2011). Dari sekian banyak teori maupun "tools" yang telah dipresentasikan oleh para peneliti, model Competing Values Framework (CVF) dari Cameron dan Quinn (2006) telah diterima secara luas dalam penelitian budaya organisasi (Chin-Loy dan Mujtaba, 2007), lebih dari 1.000 organisasi telah menggunakan konsepsi tersebut (Cameron and Quinn, 2006). Organisasi biasanya memiliki satu atau kombinasi dari empat tipe budaya organisasi, yaitu: clan, adhocracy, market, dan hierarchy (Cameron dan Quinn, 2006).

Budaya clan - merupakan tempat kerja yang bersahabat, para karyawan bisa berbagi banyak hal. Karakteristik utama dari budaya yang berorientasi pada clan adalah: tim kerja, program-program yang melibatkan karyawan, tingginya komitmen para karyawan terhadap organisasi dan rekan kerja, dan tingginya komitmen organisasi pada karyawan (Suppiah dan Sandhu, 2011; Cameron dan Quinn, 2006).

Budaya adhocracy-organisasi yang berorientasi pada budaya ini biasanya bersifat organis, bukan mekanistis. Ciri khas dari budaya ini adalah tempat kerja yang dinamis, entrepreneurial, dan kreatif. Karyawan di budaya adhocracy diberdayakan dan didorong untuk berani mengambil resiko. Kepemimpinan yang efektif budaya ini adalah visionary, inovatif, dan berorientasi pada resiko (Suppiah dan Sandhu, 2011; Cameron dan Quinn, 2006).

Budaya market - fokus utama dari budaya ini adalah mengelola transaksi dengan pihak stakeholders untuk menciptakan keunggulan kompetitif. Competitiveness dan produktivitas merupakan 
bentuk dasar yang menjadi pondasi organisasi yang berorientasi pada budaya market. Kemenangan merupakan "segalanya" bagi budaya ini dan sifat kompetitif tersebut diharapkan meresap sampai ke tingkatan individu. Pengetahuan merupakan wali bagi kekuatan, hal ini akan menciptakan ketidakstabilan dalam aktivitas berbagi pengetahuan (Suppiah dan Sandhu, 2011; Cameron dan Quinn, 2006).

Budaya hierarchy organisasi yang dominan pada budaya ini dicirikan oleh struktur formal dan struktur hirarki yang panjang. Prosedur terstandardisasi merupakan pengarah utama tindakan para karyawan dan hanya ada sedikit atau tidak ada kekuatan diskresi yang melekat pada karyawan. Penekanan utama organisasi adalah reinforcement dan concern jangka panjang organisasi adalah stabilitas dan predictability (Suppiah dan Sandhu, 2011; Cameron dan Quinn, 2006).

Berbagi pengetahuan (knowledge sharing) terjadi karena interaksi yang luas diantara para karyawan, yang saling mendistribusikan dan menyerap pengetahuan dan pengalaman (Senge, 1997). Artinya, interaksi sosial merupakan pengungkit dari aktivitas berbagi pengetahuan, tidak diungkit oleh struktur organisasi maupun peralatan/ teknologi yang ada dalam organisasi. Selain itu, berbagi pengetahuan lebih dari sekedar mengirimkan pengetahuan, tetapi juga menciptakan pengetahuan - lebih banyak menghasilkan pengetahuan daripada mengeksploitasi pengetahuan (Hooff dan Huysman, 2009). Ketika karyawan memiliki keinginan untuk berbagi pengetahuan, maka hal tersebut akan menyebabkan terjadinya proses menciptakan pengetahuan baru atau mengkombinasi pengetahuan yang ada (Holdt, 2007). Outcome-nya, aktivitas berbagi pengetahuan menolong organisasi dalam menurunkan biaya, lebih cepat dalam merespon kebutuhan pelanggan, meningkatkan produk dan layanan, memperbaiki proses-proses bisnis, serta meningkatkan pangsa pasar (Law dan Ngai, 2008).

Berbagi pengetahuan merupakan faktor terpenting dalam implementasi manajemen pengetahuan (Mason dan Pauleen, 2003; Gupta et al., 2000). Berbagi pengetahuan merupakan tool baru bagi organisasi dalam rangka menghasilkan inovasi (Wang dan Yang, 2007). Organisasi yang tidak memiliki praktik berbagi pengetahuan yang efektif dan efisien akan gagal dalam memperoleh manfaat inovasi bisnis dan pertumbuhan dari intelektual kapital karyawannya (Raharso dan Tjahjawati, 2014).

Proses berbagi pengetahuan terdiri dari aktivitas "supply dan demand" terhadap pengetahuan baru
(Ardichvili et al., 2003); artinya, ada karyawan yang membutuhkan pengetahuan baru dan ada pula karyawan yang menawarkan pengetahuan yang mereka miliki. Oleh Weggeman (2000) proses berbagi pengetahuan dibagi menjadi dua, knowledge source dan knowledge receiver. Sedangkan Oldenkamp (2001) menjelaskan proses berbagi pengetahuan dengan terminologi knowledge carrier dan knowledge requester. Van den Hooff dan de Ridder (2004) memberi label knowledge donating dan knowledge collecting dalam menjelaskan proses berbagi pengetahuan. Knowledge donating merujuk pada komunikasi modal intelektual yang dimiliki karyawan kepada karyawan yang lain. Knowledge collecting merujuk pada aktivitas berkonsultasi dengan rekan kerja dalam rangka mendapatkan pengetahuan yang dimiliki orang rekan tersebut

Berikutnya, kemampuan untuk merespon perubahan yang tidak dapat diprediksi, secara cepat dan efektif dikenal sebagai agilitas (Harraf et al., 2015; Yeganegi dan Azar, 2012); merupakan kebutuhan penting bagi bisnis yang ingin survive; bukan lagi sebuah pilihan (Harraf et al., 2015). Oleh karenanya, Goldman et al. (1995) mendefinisikan agilitas organisasi sebagai kemampuan beroperasi secara menguntungkan dalam lingkungan yang kompetitif dan lingkungan pelanggan yang semakin sulit diprediksi.

Sharifi dan Zhang (1999) melihat agilitas sebagai kemampuan organisasi untuk sense, perceive, dan predict perubahan yang telah terjadi di lingkungan bisnis mereka. Agilitas organisasi merujuk pada lingkungan bisnis yang tidak aman dan tidak dapat diprediksi. Oleh karena itu, organisasi membutuhkan kapabilitas khusus dalam rangka "merawat" perubahan, keadaan yang tidak aman, serta situasi yang tidak dapat diprediksi; kapabilitas tersebut adalah: responsiveness, competency, flexibility, dan speed (Zhang dan Sharifi, 2000). Pendekatan ini dipandang sebagai kerangka kerja yang paling komprehensif untuk mengidentifikasi karakteristik penting yang dibutuhkan untuk mewujudkan agilitas organisasi (Almahamid, 2008).

Responsiveness merujuk pada kemampuan untuk mengenali perubahan, bereaksi secara cepat terhadap perubahan tersebut, serta mengambil keuntungan dari perubahan tersebut. Competency, berhubungan dengan kemampuan untuk mencapai sasaran dan tujuan-tujuan organisasi. Sedangkan flexibility merujuk pada kemampuan untuk membuat maju atau modern berbagai macam proses serta mencapai bermacam-macam tujuan melalui 
pemanfaatan persediaan dan fasilitas yang sudah ada. Berikutnya, speed atau quickness merujuk pada kemampuan untuk menjalankan berbagai macam aktivitas dalam batas waktu yang pendek (Taghizadeh, 2015).

Budaya organisasi merupakan pondasi nilai-nilai yang mendefinisikan mengapa dan bagaimana organisasi bertindak dengan merujuk pada kondisi dan karakteristik organisasi yang menyediakan konteks intelektual dan sosial yang dibutuhkan untuk melancarkan proses-proses dalam organisasi (Jafarnejad dan Shahai, 2010). Artinya, budaya organisasi merupakan tindakan pro-aktif dalam rangka mengantisipasi apa yang terjadi di lingkungan organisasi.

Ketika lingkungan bisnis berubah dengan sangat cepat, maka organisasi juga perlu membenahi diri dengan menjadi lebih lincah dalam menghadapi tantangan tersebut. Alternatif menjadi organisasi yang lebih lincah (agile) diantisipasi oleh budaya organisasi. Hal ini sesuai dengan kajian yang dilakukan oleh Institute of T-Kearny, yang menyatakan bahwa kelincahan organisasi sangat ditentukan oleh budaya dan nilai-nilai (Jafarnejad dan Shahai, 2010). Kemampuan perusahaan untuk beradaptasi, terutama dalam lingkungan yang cepat sekali berubah, sangat tergantung pada budaya organisasi dan manajemen tim yang paripurna (Yang, 2015). Dengan demikian, competing value framework Cameron dan Quinn (2006) merupakan pondasi untuk menciptakan agilitas organisasi, disesuaikan dengan lingkungan bisnis yang dihadapi oleh setiap organisasi. Setiap tipe budaya organisasi - clan, adhocracy, market, dan hierarchy merupakan proxy dari agilitas organisasi. Berdasarkan kajian tersebut, maka hipotesis penelitian berikut ini dapat diformulasikan:

$\mathrm{H}_{1}$ : Budaya organisasi berpengaruh positif terhadap agilitas organisasi.

De Long dan Fahey (2000) menyatakan hampir semua pimpinan menyatakan bahwa budaya organisasi merupakan penghalang paling signifikan dalam menciptakan dan mengungkit knowledge assets atau enggan untuk berbagi pengetahuan (Davenport dan Prusak, 1998). Secara umum, karyawan lebih termotivasi untuk "menyimpan" pengetahuan untuk mereka sendiri, dalam rangka mendapatkan keuntungan pribadi (Milne, 2007). Peribahasa yang mengatakan "knowledge is power" merupakan gambaran yang tepat mengapa para karyawan melakukan knowledge hoarding daripada knowledge sharing. Akan tetapi, budaya organisasi bersifat multi dimensional (Schein, 2009). Para peneliti berargumentasi bahwa budaya organisasi juga menjadi pendorong aktivitas berbagi pengetahuan apabila organisasi mengembangkan sisteminsentif yang tepat, kepercayaan, kepemimpinan, struktur organisasi, maupun teknologi (Suppiah dan Sandhu, 2011; Lin, 2007; Al-Alawi et al., 2007).

Tipe budaya organisasi dari Cameron dan Quinn (2006), secara individual maupun holistik, membutuhkan komunikasi antara pimpinan dengan karyawan maupun antar karyawan itu sendiri. Oleh karena itu, iklim komunikasi dalam organisasi disarankan oleh Van den Hooff dan Van Weenen (2004) sebagai anteseden dari aktivitas berbagi pengetahuan. Ketika karyawan, dari berbagai tipe budaya organisasi, saling berinteraksi atau berkomunikasi, maka aktivitas transfer pengetahuan juga terjadi (Suppiah dan Sandhu, 2011; Rai, 2011; Smith dan Rupp, 2002). Hal ini sejalan dengan Rai (2011) yang menyatakan bahwa budaya organisasi merupakan faktor kritis dalam membangun dan memperkuat manajemen pengetahuan dalam organisasi. Dastaviz dan Jamshidy (2014) secara eksplisit menyatakan bahwa competing value framework dari Cameron dan Quinn (2006) mampu meningkatkan aktivitas rantai pengetahuan dalam organisasi, implisit di dalamnya adalah aktivitas berbagi pengetahuan. Berdasarkan kajian tersebut, maka peneliti dapat membuat hipotesis sebagai berikut:

$\mathrm{H}_{2}$ : Budaya organisasi memiliki pengaruh positif terhadap aktivitas berbagi pengetahuan.

Goldman et al. (1995) agilitas organisasi sebaiknya dibangun di atas empat pondasi, yaitu: kerja sama internal dan eksternal, struktur yang kreatif dan fleksibel, organisasi berbasis pengetahuan, dan memuaskan pelanggan. Organisasi berbasis pengetahuan merupakan organisasi yang menempatkan pengetahuan sebagai sumber daya penting organisasi (Nahapiet dan Ghoshal, 1998). Konsekuensinya, organisasi perlu menerapkan manajemen pengetahuan untuk mendapatkan manfaat pengetahuan secara optimal (Raharso dan Tjahjawati, 2014). Agilitas merupakan kemampuan menggunakan pengetahuan untuk mengeksploitasi kesempatan yang menguntungkan dalam market place yang volatil (Naylor et al., 1999). Di pihak lain, aktivitas berbagi pengetahuan merupakan bagian terpenting dari manajemen pengetahuan (Raharso, 2016). Jadi, membangun agilitas organisasi memiliki hubungan yang erat dengan aktivitas berbagi pengetahuan. Aktivitas berbagi 
pengetahuan merupakan faktor kunci agar organisasi sukses mengaplikasikan agilitas organisasi (Sarshar dan Hezarjaribi, 2016), merupakan kunci utama untuk merespon secara cepat dan proaktif semua perubahan lingkungan bisnis (Almahamid, 2008; Razak et al., 2016).

Semua dimensi dari Goldman et al. (1995) juga merujuk pada pengetahuan dan bagaimana mengelola pengetahuan (Yaghoubi dan Dahmardeh, 2011). Kerja sama di dalam maupun di luar organisasi membutuhkan pertukaran pengetahuan di antara karyawan di dalam organisasi maupun pertukaran pengetahuan antar karyawan dari berbagai organisasi (Turban et al., 2003). Struktur organisasi yang kreatif dan fleksibel diperlukan oleh organisasi yang lincah (agile) karena struktur tersebut diharapkan bisa me-reorganisasi individu dan unit agar mampu mewujudkan kebutuhan dan tujuan organisasi (Wang dan Ahmed, 2003). Pada saat yang sama, struktur tersebut juga dibutuhkan dalam organisasi berbasis pengetahuan (Yaghoubi dan Dahmardeh, 2011). Terakhir, untuk memuaskan pelanggan, hal tersebut dapat dicapai apabila organisasi memiliki kemampuan dalam berinovasi. Kapabilitas inovasi suatu organisasi menyebabkan organisasi mampu mengikuti dinamika kebutuhan konsumen, sehingga konsumen tidak hanya puas tetapi juga delight (Raharso, 2005). Dalam perspektif manajemen pengetahuan, berbagi pengetahuan memicu organisasi untuk memiliki kapabilitas inovasi (Liebowitz, 2002; Raharso dan Tjahjawati, 2014). Aktivitas knowledge collecting dan knowledge donating (sebagai dimensi dari aktivitas berbagi pengetahuan), menurut Lin (2007) dan Jantunen (2005), akan menciptakan kapabilitas inovasi yang superior. Dengan demikian, kajian tersebut menyebabkan peneliti dapat membuat hipotesis sebagai berikut:

$\mathrm{H}_{3}$ : Berbagi pengetahuan berpengaruh positif terhadap agilitas organisasi.

\section{METODE PENELITIAN}

Penelitian ini menggunakan basis survei sebagai metode untuk mengumpulkan data. Terdapat tiga variabel yang digunakan dalam penelitian ini, yaitu: budaya organisasi, berbagi pengetahuan, dan agilitas organisasi.

Survei budaya organisasi, berbagi pengetahuan, dan agilitas organisasi dilakukan melalui angket yang terstruktur dan standardized close ended; data diperoleh dengan skala lima poin Likert; $1=$ sangat tidak setuju dan 5=sangat setuju. Penilaian budaya organisasi menggunakan Organizational Culture
Assesment Instrument (OCAI) dari Cameron dan Quinn (2006), terdiri dari empat dimensi, yaitu: clan, adhocracy, market, dan hierarchy. Survei berbagi pengetahuan menggunakan instrumen yang dikembangkan oleh Van den Hooff dan Van Weenen (2004), terdiri dari dua proses: knowledge collecting dan knowledge donating. Untuk agilitas organisasi, peneliti menggunakan instrumen dari Almahamid (2008), yang dibangun berdasarkan kerangka kerja dari Zhang dan Sharifi (2000), memiliki empat dimensi, yaitu: responsiveness, competency, flexibility, dan speed atau quickness.

Penelitian dilakukan terhadap perusahaan swasta yang memiliki karyawan lebih dari 100 (Suppiah dan Sandhu, 2011). Dari berbagai perusahaan di Bandung yang ditawari untuk menjadi partisipan penelitian, ada tiga perusahaan yang bersedia bekerja sama, yaitu: perusahaan ritel busana muslim, produsen peralatan listrik, dan produsen spare part motor.

Angket terbagi menjadi dua bagian. Bagian pertama mengindikasikan profil demografi responden, bagian kedua berisi pertanyaan yang harus direspon oleh responden mengenai budaya organisasi, berbagi pengetahuan, dan agilitas organisasi. Total 450 angket didistribusikan, 394 angket dikembalikan dan layak untuk diproses. Dengan demikian tingkatan respon adalah $87,56 \%$ - lebih besar dari 30\% - sehingga memungkinkan untuk melakukan generalisasi (Sekaran, 2007)

Uji validitas dan reliabilitas digunakan untuk memastikan bahwa alat ukur yang digunakan dalam penelitian ini valid dan reliabel. Selanjutnya, model penelitian dievaluasi dengan menggunakan teknik regresi ganda, dan disajikan dalam format model struktural dengan koefisien jalur.

\section{HASIL DAN PEMBAHASAN}

Partisipan penelitian ini berasal dari perusahaan yang bergerak dalam bidang ritel busana muslim, produsen peralatan listrik, dan produsen spare part motor; semuanya berkedudukan di Bandung. Berdasarkan jenis kelamin, 59 persen adalah pria dan sisanya wanita, artinya tenaga kerja di organisasi bisnis tersebut akomodatif terhadap semua gender. Selanjutnya, kurang lebih separuh responden berusia 21-30 tahun (56 persen), berusia <20 tahun sebanyak 9 persen, berusia 31-40 tahun sebanyak 18 persen dan 17 persen berusia $>40$ tahun. Anak muda yang bekerja pada usia tersebut didominasi lulusan SLTA (74 persen ), artinya bisnis di bidang tersebut belum memerlukan lulusan perguruan tinggi. Terbukti, responden yang bependidikan program 
Diploma $1 / 2 / 3$ hanya $9 \%$, berpendidikan D4/S1 sebanyak 17 persen, dan sisanya adalah S2/3 (1 persen). Terakhir, dilihat dari masa kerja, hampir separuh responden bekerja kurang dari lima tahun (45 persen ); sisanya telah bekerja selama 6-10 tahun (29 persen), bermasa kerja 11-15 tahun sebanyak 7 persen, dan sisanya telah bekerja $>15$ tahun (19 persen).

Reliabilitas data diuji terlebih dahulu dengan uji validitas, uji reliabilitas, serta korelasi antar variabel. Instrumen dinyatakan reliabel apabila tidak dipengaruhi oleh random error (Forza dan Filippini, 1998). Reliabilitas umumnya diukur dengan menggunakan Cronbach alpha. Konstruk budaya organisasi, berbagi pengetahuan, dan agilitas organisasi masing-masing memiliki nilai Cronbach alpha sebesar 0,901; 0,810; dan 0,930. Menurut Hair et al. (2006), nilai Cronbach alpha >0,70 merupakan nilai internal consistency reliability yang dapat diterima. Dengan demikian konstruk budaya organisasi, berbagi pengetahuan, dan agilitas organisasi, yang digunakan dalam penelitian ini, memiliki nilai internal consistency yang tergolong bagus.

Korelasi antara item dengan total untuk konstruk budaya organisasi, berbagi pengetahuan, serta agilitas organisasi masing-masing memiliki nilai berkisar antara 0,399-0,583; 0,433-0,612; dan 0,3490,624 . Dengan demikian semua instrumen yang digunakan dalam mengukur budaya organisasi, berbagi pengetahuan, dan agilitas organisasi bersifat valid, karena memiliki nilai $>0,30$ (Sekaran, 2007). Peneliti juga mendayagunakan statistik korelasional untuk mendapatkan bukti adanya convergent validity (Suppiah dan Sandhu, 2011).

Tabel 1. Matrik Korelasi antar Dimensi per Variabel

\begin{tabular}{|c|c|c|c|c|}
\hline Budaya Organisasi & Clan & dhocracy & Market & Hierarchy \\
\hline Clan & 1 & $0,567 *$ & $0,522 *$ & $0,605 *$ \\
\hline Adhocracy & & 1 & $0,599 *$ & $0,467 *$ \\
\hline Market & & & 1 & $0,538 *$ \\
\hline Hierarchy & & & & 1 \\
\hline Berbagi Pengetahuan & \multicolumn{2}{|c|}{ Knowledge Collecting } & \multicolumn{2}{|c|}{ Knowledge Donating } \\
\hline Knowledge Collecting & \multicolumn{2}{|c|}{1} & \multicolumn{2}{|c|}{$0,553^{*}$} \\
\hline Knowledge Donating & & & \multicolumn{2}{|c|}{1} \\
\hline Agilitas Organisasi & Responsiveness & Competency & $\begin{array}{c}\text { Quickness/ } \\
\text { Speed }\end{array}$ & Flexibility \\
\hline Responsiveness & 1 & $0,636^{*}$ & $0,523 *$ & $0,684 *$ \\
\hline Competency & & 1 & $0,626^{*}$ & $0,614^{*}$ \\
\hline Quickness/Speed & & & 1 & $0,624 *$ \\
\hline Flexibility & & & & 1 \\
\hline
\end{tabular}

Catatan: korelasi signifikan pada tingkat 0,01 (2-tailed)

Sumber: hasil olah data, 2018

Dimensi-dimensi budaya organisasi dari Cameron dan Quinn (2006); berbagi pengetahuan dari Van den Hooff dan Van Weenen (2004); dan agilitas organisasi dari Almahamid (2008) memiliki koefisien korelasi yang secara statistik berbeda dengan nol $(\mathrm{p}<0,01)$ dan memiliki korelasi yang agak tinggi tetapi tidak mendekati 1 (Tabel 1). Berdasarkan koefisien korelasi, peneliti menyatakan bahwa dimensi-dimensi budaya organisasi, berbagi pengetahuan, dan agilitas organisasi mendukung pengukuran variabel budaya organisasi, berbagi pengetahuan, dan agilitas organisasi karena koefisien korelasinya tidak terlalu tinggi (mendekati angka 1); hal ini mengindikasikan adanya "dept" dan "diversity" dari konstruk budaya organisasi, berbagi pengetahuan, dan agilitas organisasi (Suppiah dan
Sandhu, 2011), selain itu semua korelasinya positif. Perlu ditambahkan, karena semua korelasi bivariate memiliki nilai kurang dari $0,85(|r|<0,85)$, korelasi Pearson mengindikasikan tidak adanya masalah multikolinearitas (Lei dan $\mathrm{Wu}, 2007$ ).

Kesimpulannya, konstruk budaya organisasi, berbagi pengetahuan, serta agilitas organisasi yang digunakan dalam penelitian ini tergolong valid dan reliabel (Sekaran, 2007; Hair et al., 2006; Suppiah dan Sandhu, 2011).

Hasil analisis deskriptif menunjukkan nilai ratarata konstruk budaya organisasi, berbagi pengetahuan, serta agilitas organisasi berada dalam level "tinggi" (berada dalam range 3,41-4,20, skala 5; Tabel 2). Agilitas organisasi memiliki nilai ratarata paling rendah $(3,717)$, sedangkan berbagi 
146 Matrik: Jurnal Manajemen, Strategi Bisnis dan Kewirausahaan Vol. 12, No. 2, Agustus 2018

Tabel 2. Rata-rata dan Matrik Korelasi antar Variabel

\begin{tabular}{llccccc}
\hline \multicolumn{1}{c}{ Variabel } & Rata2 & Dev. Stand. & 1 & 2 & 3 \\
\hline 1 & Budaya Organisasi & 3,791 & 0,3956 & 1 & $0,541^{* *}$ & $0,641^{* *}$ \\
2 & Berbagi Pengetahuan & 4,012 & 0,4556 & & 1 & $0,446 * *$ \\
3 & Agilitas Organisasi & 3,717 & 0,4024 & & & 1 \\
\hline ** Korelasi signifikan pada tingkat $0,01$. & & & & \\
Sumber: hasil olah data, 2018 &
\end{tabular}

pengetahuan memiliki nilai rata-rata yang tertinggi $(4,012)$. Dilihat dari deviasi standar, semua variabel berada dalam range yang masih dapat ditoleransi, yaitu: maksimal 20 persen dari nilai rata-rata (Santoso, 2000).

Berikutnya, korelasi antara konstruk atau variabel (budaya organisasi, berbagi pengetahuan, dan agilitas organisasi) bersifat signifikan. Hal ini mengindikasikan bahwa budaya organisasi, berbagi pengetahuan, dan agilitas organisasi memiliki interkoneksi (Ellonen et al., 2008). Hal ini menunjukkan bahwa penelitian ini memenuhi syarat criterion-related validity atau predictive validity; sebab semua dimensi variabel bebas memiliki relasi yang signifikan dengan variabel terikat (Das et al., 2008).

\section{Relasi Antar Variabel}

Penelitian ini bermanfaat untuk memahami peran budaya organisasi serta berbagi pengetahuan dalam membangun agilitas organisasi. Penelitian ini berhasil membuktikan adanya pengaruh yang signifikan dari konstruk budaya organisasi terhadap berbagi pengetahuan dan agilitas organisasi, dan pengaruh signifikan berbagi pengetahuan terhadap agilitas organisasi.

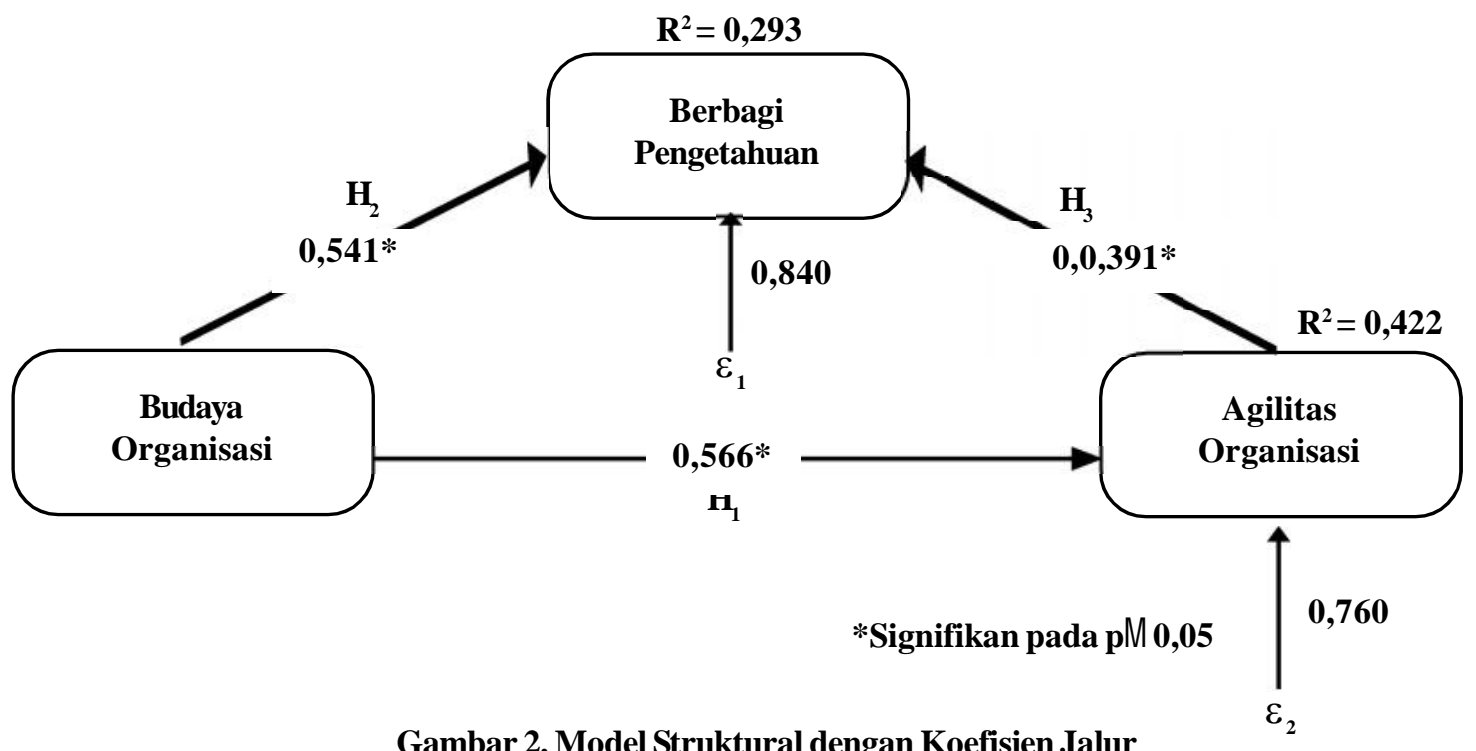

Gambar 2. Model Struktural dengan Koefisien Jalur

Sumber: Hasil olah data, 2017

\section{Relasi Budaya Organisasi dengan Agilitas Organisasi $\left(\mathbf{H}_{1}\right)$}

Budaya organisasi memiliki pengaruh positif dan signifikan dengan agilitas organisasi, memiliki koefisien jalur 0,566 (Gambar 2). Selain itu, budaya organisasi mampu menjelaskan 42,2 persenvariasi yang ada dalam variabel agilitas organisasi (simultan dengan variabel berbagi pengetahuan). Hal ini dapat terjadi karena budaya organisasi merupakan fondasi dasar terciptanya agilitas organisasi. Budaya organisasi menyediakan "identitas makro" bagi seluruh anggota organisasi untuk merespon lingkungan turbulent dengan agilitas. Budaya organisasi merupakan platform bersama bagi anggota organisasi untuk melakukan berbagai tindakan antisipatif maupun proaktif terhadap semua perubahan yang terjadi dalam lingkungan organisasi. Budaya organisasi bertindak sebagai kontrak psikologis antara individu dengan organisasi (Rousseau, 1995) untuk mendukung terlaksananya upaya-upaya proaktif agar dapat memperoleh manfaat dari perubahana lingkungan bisnis yang bersifat turbulent. 
Membangun agilitas organisasi merupakan upaya yang berkelanjutan, bukan program jangka pendek. Sebab, lingkungan bisnis selalu berubah tanpa dapat diprediksi ke mana arahnya. Jadi, masalah sebenarnya dari membangun agilitas organisasi adalah melakukan penyelarasan antara struktur, proses, dan sistem yang ada dalam organisasi (Mehrabi et al., 2013); yang semuanya harus sesuai dengan platform budaya yang telah ada.

\section{Relasi Budaya Organisasi dengan Berbagi Pengetahuan $\left(\mathrm{H}_{2}\right)$}

Budaya organisasi memiliki pengaruh yang positif dan signifikan terhadap berbagi pengetahuan (dengan koefisien jalur=0,541), serta mampu menjelaskan 29,3\% variasi yang ada dalam berbagi pengetahuan. Jadi, dalam hal ini budaya organisasi memainkan peran sebagai promotor aktivitas berbagi pengetahuan.

Agar efektif, aktivitas berbagi pengetahuan membutuhkan budaya organisasi yang memberikan iklim kondusif untuk melakukan aktivitas tersebut (Andam, 2017). Semua interaksi anggota organisasi berada dalam bingkai budaya organisasi. Oleh karena itu, walaupun berbagai variabel bisa menjadi pengungkit aktivitas berbagi pengetahuan, akan tetapi variabel budaya organisasi merupakan variabel yang secara konsisten memiliki pengaruh yang signifikan terhadap berbagi pengetahuan (Abzari dan Teimouri, 2008; Al-Alawi et al., 2007; Roman-Velazquez, 2005). Tidak mengherankan apabila Robert Buckman, presiden, chairman, dan CEO dari Bulab Holding, Inc. menyatakan ada tiga faktor kritis dalam manajemen pengetahuan, yaitu: budaya, budaya, dan budaya (O’Dell dan Grayson, 1998).

\section{Relasi Berbagi Pengetahuan dengan Agilitas Organisasi $\left(\mathbf{H}_{3}\right)$}

Variabel berbagi pengetahuan memiliki pengaruh positif dan signifikan terhadap agilitas organisasi, dengan koefisien jalur $=0,139$, dan mampu menjelaskan 42,2 persen variasi yang ada dalam variabel agilitas organisasi (secara simultan dengan variabel budaya organisasi). Hal ini dapat terjadi karena aktivitas berbagi pengetahuan, dalam bentuk knowledge collecting maupun knowledge donating, akan meningkatkan kapasitas individu untuk mendefinisikan sebuah situasi atau masalah, dan mengaplikasikan pengetahuan yang mereka miliki untuk menyelesaikan masalah (Nonaka et al., 2006). Jadi, berbagi pengetahuan di antara karyawan menstimulasi setiap karyawan untuk berpikir secara kritis dan lebih kreatif, serta menghasilkan pengetahuan baru (Aulawi et al., 2009). Pengetahuan tersebut selanjutnya dapat diberdayakan untuk menghasilkan ide-ide baru, yang berguna untuk menyelesaikan masalah yang muncul di organisasi, atau menghasilkan inovasi dalam bidang-bidang tertentu sehingga kepuasan pelangan meningkat (Jantunen, 2005). Dalam hal ini, pengetahuan merupakan sumber daya inti (core resource) bagi pembentukan agilitas organisasi, yang akan ditransformasikan menjadi produk atau layanan (Biao-wen, 2010) yang bisa memenuhi kebutuhan atau keinginan konsumen yang bersifat dinamis.

Aktivitas berbagi pengetahuan memberikan "identitas mikro" (bagi anggota organisasi) dalam bentuk pemahaman terhadap makna dari semua perubahan lingkungan bisnis yang menerpa organisasi. Ketika perubahan menerpa organisasi, langkah awal yang dilakukan oleh karyawan adalah melakukan interaksi dengan karyawan yang lain untuk mendapatkan maupun memberikan makna dari perubahan tersebut. Interaksi tersebut akan mengalirkan pengalaman, ketrampilan, maupun informasi yang akan digunakan oleh setiap karyawan untuk merubah atau bahkan melakukan transformasi sikap dan perilaku kerja yang lebih cocok dengan lingkungan yang baru tersebut. Hal ini sesuai dengan pendapat Razak (2016) yang menyatakan bahwa praktik-praktik berbagi pengetahuan bermanfaat dalam merespon perubahan lingkungan.

Hasil regresi ganda menunjukkan adanya pengaruh yang signifikan dari variabel budaya organisasi terhadap variabel berbagi pengetahuan dan agilitas organisasi; serta pengaruh yang signifikan dari variabel berbagi pengetahuan terhadap agilitas organisasi. Artinya, semua hipotesis penelitian dapat dibuktikan pada studi empiris ini.

Berikutnya, untuk mengidentifikasi apakah variabel berbagi pengetahuan memiliki peran sebagai mediator yang efektif antara budaya organisasi dengan agilitas organisasi, maka analisis berikut ini merupakan jawabannya (Tabel 3).

Tabel 3. Pengaruh Budaya Organisasi terhadap Agilitas Organisasi

\begin{tabular}{ccc}
\hline & Pengaruh & \\
\hline Langsung & $\begin{array}{c}\text { Tidak Langsung } \\
\text { (via berbagi pengetahuan) }\end{array}$ & Total \\
\hline 0,566 & $0,541^{*} 0,139=0,075199$ & 0,641199 \\
\hline
\end{tabular}

Sumber: hasil olah data, 2018 
Ketika pengaruh langsung variabel budaya organisasi terhadap variabel agilitas organisasi $(0,566)$ nilainya lebih besar dari pengaruh tidak langsung budaya organisasi terhadap agilitas organisasi (melalui variabel berbagi pengetahuan, sebesar 0,0752) maka variabel berbagi pengetahuan bukan merupakan mediator yang baik bagi budaya organisasi untuk mempengaruhi agilitas organisasi. Hal ini terjadi karena budaya organisasi secara langsung memberikan "pondasi" agar agilitas organisasi bisa terbangun. Misal, ketika organisasi memiliki budaya untuk bekerja dalam tim, maka anggota tim memiliki kesempatan untuk mengembangkan potensi diri mereka dalam bentuk kerjasama yang sinergis dengan rekan kerja sehingga berbagai masalah perubahan lingkungan bisnis bisa diantisipasi atau diselesaikan dengan baik. Oleh karena itu, perlu dikembangkan budaya organisasi agar mampu menjadi "fasilitator" yang tepat dalam membangun agilitas organisasi.

\section{Keterbatasan Penelitian}

Terdapat beberapa keterbatasan selama penelitian ini dilakukan. Jumlah organisasi yang turut berpartisipasi dalam studi ini masih terlalu sedikit, sehingga spektrum tipe budaya organisasi yang dapat digambarkan masih bersifat sempit. Selain itu, pengumpulan data dengan skala Likert lima poin - untuk variabel budaya organisasi - kurang memberikan keunikan atau perbedaan budaya organisasi dari masing-masing organisasi. Untuk itu, walaupun lebih rumit, perlu dicoba untuk menggunakan ipsative rating scale (Cameron dan Quinn, 2006).

\section{Penelitian Selanjutnya}

Studi ini memberi penekanan pada budaya organisasi sebagai sebuah dimensi tunggal, untuk itu perlu diteliti bagaimana relasi dari masing-masing tipe budaya terhadap aktivitas berbagi pengetahuan maupun agilitas organisasi. Lebih jauh lagi, karena budaya organisasi merupakan pondasi dari semua aktivitas organisasi, maka perlu diidentifikasi bentukbentuk budaya organisasi yang bisa menjadi fasilitator dalam mengembangkan agilitas organisasi.

Selain itu, karena bentuk pengetahuan yang ada di organisasi lebih bersifat tacit, yang tersimpan dalam pikiran karyawan, maka aktivitas berbagi pengetahuan lebih difokuskan pada bentuk pengetahuan tacit, bukan explicit (Suppiah dan Sandhu, 2011). Smith (2001) melaporkan bahwa 90 persen pengetahuan yang ada di suatu organisasi ternyata melekat dan disintesis dalam kepala para karyawan. Pengetahuan tersebut bersifat personal, context specific, serta sulit diformalkan dan sulit dikomunikasikan (Nonaka dan Takeuchi, 1995).

Budaya yang mendukung pada aktivitas berbagi pengetahuan, khususnya yang bersifat tacit, juga perlu diteliti untuk memberikan gambaran yang lebih operasional bagaimana cara mendayagunakan pengetahuan tacit untuk menciptakan keunggulan organisasi secara umum, atau secara khusus menciptakan organisasi yang agile.

\section{SIMPULAN DAN SARAN Simpulan}

Kajian yang bersifat eksploratori ini merupakan upaya untuk merelasikan kapabilitas yang diperlukan untuk membangun agilitas organisasi dengan budaya organisasi dan aktivitas berbagi pengetahuan. Penelitian ini juga memperkaya literatur dengan mengkonfirmasi bahwa agilitas organisasi dalam lingkungan yang tidak pasti, tidak dapat diprediksi, volatile, dinamis, dan selalu berubah dapat dibangun melalui praktik-praktik budaya organisasi dan aktivitas berbagi pengetahuan.

Studi ini juga memperkaya kajian aktivitas berbagi pengetahuan dan memperjelas arti penting berbagi pengetahuan dalam membangun sikap yang proaktif terhadap lingkungan bisnis yang terus berubah. Dalam lingkungan bisnis yang dinamis, sumber daya perusahaan berupa pengetahuan merupakan sumber daya yang menjanjikan eksistensi organisasi bisnis agar terus terjaga.

\section{Saran}

Penelitian ini menghasilkan saran yang dapat dimanfaatkan oleh para praktisi maupun peneliti. Walaupun budaya organisasi terbukti memberi pengaruh yang signifikan terhadap berbagi pengetahuan maupun agilitas organisasi, akan tetapi perlu diidentifikasi "komposisi tipe budaya" yang dibutuhkan untuk membangun dua variabel tersebut. Hal ini penting dilakukan, karena organisasi jarang hanya memiliki satu tipe budaya organisasi saja.

Aktivitas berbagi pengetahuan juga memberikan peran yang signifikan terhadap pengembangan agilitas organisasi. Akan tetapi, karena pengetahuan yang paling dominan dalam suatu organisasi adalah pengetahuan tacit, maka perlu upaya-upaya untuk memberdayakan pengetahuan tacit.

Eksistensi organisasi merupakan tujuan utama perusahaan, oleh karena itu konsep agilitas organisasi perlu disinergikan dengan berbagai konsep lainnya agar organisasi benar-benar survive. Semua faktor 
yang menjadi pengungkit agilitas organisasi dan semua variabel yang menjadi pengungkit agar organisasi tetap survive sebaiknya tetap dipertimbangkan. Tidak sekedar bertumpu pada agilitas organisasi saja.

\section{REFERENSI}

Abzari, M. and Teimouri, H. 2008. The effective factors on knowledge sharing in organizations. The International Journal of Knowledge, Culture and Change Management, 8(2), pp. 106-113.

Al-Alawi, A.I., Al-Marzooqi, N.Y., and Mohammed, Y.F. 2007. Organizational culture and knowledge sharing: critical success factors. Journal of Knowledge Management, 11(2), pp. 22-42.

Alattas, M.I. and Kang, K. 2015. The relationship between organization culture and knowledge sharing towards business system success. Australasian Conference on Information Systems, December, Adelaide.

Alavi, M. and Leidner,D.E. 2001. Review: knowledge management and knowledge management systems: conceptual foundation and research issues. MIS Quaterly, 25(1), pp. 107-136.

Almahamid, S. 2008. The role of agility and knowledge sharing on competitive advantage: an empirical investigation in manufacturing companies in Jordan. POMS 19th Annual Conference, La Jolla, California, USA, May 9 to May 12.

Alzoubi, A.E., Al-Outom, F.J., and Albatainh, A.K. 2011. Factors associated affecting organization agility on product development. International Journal of Research and Reviews in Applied Sciences, 9, pp. 503-515.

Amirnejad, G. And Milad, Zahra. 2015. The effects of organizational culture on organizational agility with mediator role of sharing of knowledge headquarters of national company of the oilrich regions in South-Ahvaz. Indian Journal of Fundamentasl and Applied Life Sciences, 5(3), pp. 1521-1529.

Andam, Farshad. 2017. Knowledge sharing: exploring the links to organizational culture. International Journal of Health Economics and Policy, 2(1), pp. 16-26.

Ardichvili, A., Page, V., and Wentling, T. 2003. Motivation and barriers to participation in virtual knowledge-sharing communities of practice. Journal of Knowledge Management, 7(1), pp. 64-77.
Aulawi, H., Sudirman, I., Suryadi, K., and Govindaraju, R. 2009. Knowledge sharing behavior, antecedents and their impact on the individual innovation capability. Journal of Applied Sciences Research, 5(12), pp. 22382246.

Bhagat, R.S., Kedia, B.L., Harveston, P.D., and Triandis, H.C. 2002. Cultural variations in the cross-border transfer of organizational knowledge: an integrative framework. Academy of Management Review, 27(2), pp. 204-221.

Biao-wen, L. 2010. The analyis of obstacles and solutions for software enterprises to implement knowledge management. The 2nd IEEE International Conference on Information Management and Engineering (ICIME), pp. 211-214.

Brown, R.B. and Woodland, M. 1999. Managing knowledge wisely: a case study in organizational behavior. Journal of Applied Management Studies, 8(2), pp. 175-198.

Cameron, K.S. and Quinn, R.E. 2006. Diagnosing and Changing Organizational CultureBased on Competing Value Framework, revised edition. Reading, MA.: AddisonWesley.

Chin-Loy, C. and Mujtaba, B.G. 2007. The influence of organizational culture on the success of knowledge management practices with North American companies. International Business \& Economic Research Journal, 6(3), pp. 15-28.

Das, A., Paul, H., and Swierczek, F.W. 2008. Developing and validating total quality management (TQM) constructs in the context of Thailand's manufacturing industry. Benchmarking: an International Journal, 15(1), pp. 52-72.

Dastaviz, A.H. and Jamshidy, M. 2014. Competing value enhanced knowledge chain aktivities in a new conceptual model. Journal of Management Policies and Practices, September, 2(3), pp. 83-96.

Davenport, T.H. and Prusak, L. 1998. Working Knowledge: How Organizations Manage What They Know. Boston, MA.: Harvard Business School Press.

De Long, D.W. and Fahey, L. 2000. Diagnosing cultural barriers to knowledge. Academy of Management Executive, 14(4), pp. 113-127.

Drucker, P.F. 1968. Comeback of the entrepreneur. Management Today, April, pp. 23-30. 
Ellonen, R., Blomqvist, K., and Puumalainen, K. 2008. The role of trust in organizational innovativeness. European Journal of Innovation Management, 11(2), pp. 160-181.

Ersoy, I.B. and Mahdy, A.M. 2015. Agile knowledge sharing. International Journal Software Engineering (IJSE), 6(1), pp. 1-15.

Fahami, Z., Pordanjani, H.A.M., Mahmoudi, M.T., and Montazer-Al-Zohour, F. 2017. The study of the relationship between organizational culture and organizational agility in Agricultural Bank. Bulletin de la Societe Royale des Sciences de Liege, 86, spesial edition, pp.453-460.

Forza, C. and Filippini, R. 1998. TQM impact on quality fonformance and customer satisfaction: a causal model. International Journal of Production Economics, 55(1), pp. 1-20.

Goldman, S.L., Nagel, R.N. and Preiss, K. 1995. Agile competitors and virtual organizations: strategies for enriching the customer. New York, NY.: Van Nostrand Reinhold.

Gupta, A.K. and Govindarajan, V. 2000. Knowledge management's social dimension: lesson from Nucor Steel. Sloan Manajement Review, 42(1), pp. 71-81.

Gupta, S.G., Iyer, L.S., and Aronson, J.E. 2000. Knowledge management: practices and challenges. Industrial Management \& Data System, 100(1), pp. 17-21.

Hair Jr, J.F., Black, W.C., Babin, B.J., and Anderson, R.E. 2006. Multivariate Data Analysis. Upper Saddle River, Boston: Pearson.

Harraf, A., Wanasika, I., Tate, K. and Talbott, K. 2015. Organizational agility. The Journal of Applied Business Research, March/April, 31(2), pp. 675-686.

Holdt, C.P. 2007. Knowledge sharing: moving away from the obsession with bes practices. Journal of Knowledge Management, 11(1), pp. 36-47.

Hooff, B.V.D. and Huysman, M. 2009. Managing knowledge sharing: emergent and engineering approaches. Information \& Management, 46, pp. 1-8.

Hooff, B.V.D. and Ridder, J.A. 2004. Knowledge sharing in context: the influence of organizational commitment, communication climate and CMC use on knowledge sharing. Journal of Knowledge Management, 8(6), pp. 117-130.

Jafarnejad, A. and Shahai, B. 2010. Introduction to agility of organization and agile production. Tehran: Institute of Publishing Kind Book.

Jantunen, A. 2005. Knowledge-processing capabilities and innovative performance: an empirical study. European Journal of Innovation Management, 8(3), pp. 336-349.

Jarnagin, C. and Slocum, J.W. Jr. 2007. Creating corporate cultures through mythopoetic leadership. Organizational Dynamics, 36(3), pp. 288-302.

Law, C.C.H. and Ngai, E.W.T. 2008. An empirical study of the effects of knowledge sharing and learning behaviors on firm performance. Expert Systems with Applications, 34, pp. 2342-2349.

Lei, P.W. and Wu, Q. 2007. Introduction to structural equation modeling: issues and practical considerations. Educ. Meas. Issues Pract., 26, pp. 33-43.

Liebowitz, J. 2001. Knowledge management and its link to artificial intelligence. Expert Systems with Application, 20(1), pp. 1-6.

Liebowitz, J. 2002. Facilitating innovation through knowledge sharing: a look at the US Naval Surface Warfare Center-Carderock Division. Journal of Computer Information Systems, 42(5), pp. 1-6.

Lin, H.F. 2007. Knowledge sharing and firm innovation capability: an empirical study. International Journal of Manpower, 28(3/4), pp. 315-332.

Martin, B. 2000. Knowledge management with in the context of management: an evolving relationship. Singapore Management Review, 22(2), pp. 17-37.

Mason, D. and Pauleen, D.J. 2003. Perception of knowledge management: a qualitative analysis. Journal of Knowledge Management, 7(4), pp. 38-48.

Mehrabi, S., Siyadat, S.A., and Allameh, S.M. 2013. Studying the relationship between the process of knowledge sharing and organizational agility among personnel of Agriculture-Jahad Organization in Share-Kord. International Journal of Academic Research in Business and Social Sciences, 3(5), pp. 324-336.

Milne, P. 2007. Motivation, incentives and organizational culture. Journal of Knowledge Management, 11(6), pp. 28-38.

Nahapiet, J. and Ghoshal, S. 1998. Social capital, intellectual capital and organizational advantage. Academy of Management Review, 40(2), pp. 242-266. 
Naylor, J.B., Naim, M.M., and Berry, D. 1999. Leagility: integration the lean and agile manufacturing paradigms in the total supply chain. International Journal of Production Economics, 62, pp. 107-118.

Nonaka, I. 1991. The knowledge-creating company. Harvard Business Review, 69(6), pp. 96-104.

Nonaka, I. and Takeuchi, H. 1995. The Knowledge-creating Company: How Japanese Companies Create the Dynamics of Innovation. Oxford: Oxford University Press.

Nonaka, I., Von Krogh, G., and Voelpel, S. 2006. Organizational knowledge creation theory: evolutionary paths and future advances. Organization Studies, 27(8), pp. 1179-1208.

O'Dell, C. and Grayson, D.J., Jr. 1998. If only we knew what we know. New York: Free Press.

Oldenkamp, J. H. 2001. Successful knowledge transfer. Utrecht: Lemma BV.

Quinn, J.B., Anderson, P., and Finkelstein, S. 1998. Managing profesional intellect: making the most of the best. Strategic Management of Intellectual Capital, pp. 87-100.

Raharso, S. 2005. Pengaruh customer delight terhadap behavioral-intentions battery. Jurnal Manajemen Usahawan Indonesia, No. 5, Mei, pp. 45-53.

Raharso, S. 2016. Social capital sebagai mediator antara trust dan knowledge sharing: studi empiris di minimarket. Jurnal Manajemen, 15(2), Mei, pp. 271-290.

Raharso, S. dan Tjahjawati, S.S. 2014. Relasi proses knowledge sharing dengan kapabilitas inovasi. Jurnal Manajemen Usahawan Indonesia, 43(3), Juli-September, pp. 243-259.

Rai, R.K. 2011. Knowledge management and organizational culture: a theoretical integrative framework. Journal of Knowledge Management, 15(5), pp. 779-801.

Razak, N.A., Pangil, F., Zin, M.L.M., Yunus, N.A.M., and Asnawi, N.H. 2016. Theories of knowledge sharing behavior in business strategy. Procedia Economics and Finance, 37, pp. 545-553, Fifth International Conference on Marketing and Retailing (5th INCOMaR) 2015.

Roman-Velazquez, R. 2005. An empiric study of organizational culture types and their relationship with the success of a knowledge management system and the flow of knowledge in the US Government and nonprofit sectors.
In Stankosky, M. (Ed.). Creating the Discipline of Knowledge Management. Burlington, MA.: Butterworth-Heinemann.

Rousseau, D.M. 1995. Psychological contracts in organizations: understanding written and unwritten agreements. Thousand Oaks: Sage.

Saki, H. and Amirnejad, G. 2016. An overview on the effect of knowledge management processes on organizational agility with mediating role of organizational culture at officess of Maroun Oil and Gas Exploitation Company. Bulletin of Environment, Pharmacology and Life Sciences, Special Issue 1, pp. 82-87.

Sanchuli, M. and Yazdani, B.O. 2015. The relationship between components of organizational culture and agility of Zabol University of Medical Sciences based on the Denison organizational culture model. Buletin Teknologi Tanaman, 12(2), pp. 187-191.

Santoso, S. 2000. Buku Latihan SPSS Statistik Parametrik. Jakarta: Elex Media Komputindo.

Sarshar, E. and Hezarjaribi, H.A.N. 2016. The relationship between organizational culture with organizational agility among staff in Shefa Specialized Hospital of Heart, Golestan Province, Iran. Journal of Management Sciences, 2(5), pp 290-293.

Schein, E.H. 2004. Organizational Culture and Leadership. San Fransisco, CA.: Jossey-Bass.

Schein, E.H. 2009. The Corporate Culture Survival Guide. San Francisco, CA.: JosseyBass.

Sekaran, U. 2007. Metode Penelitian untuk Bisnis. Jilid $1 \& 2$. Diterjemahkan oleh Kwan Men Yon. Jakarta: Salemba Empat.

Senge, P. 1997. The Fifth Discipline. Measuring Business Excellence, 1(3), pp. 46-51.

Sharifi, H. and Zhang, Z. 1999. A methodology for achieving agility in manufacturing organization. International Journal of Production Economics, 62, pp. 7-22

Sharifi, H. and Zhang, Z. 2001. Agile manufacturing practice: application of a methodology. International Journal of Operations \& Production Management, 21(5/6), pp. 772-794.

Small, A.W. and Downey, A.E. 1996. Orchestrating multiple changes: a framework for managing concurrent changes of varied type and scope. Proceeding of IEMC 1996 Conference on Managing Virtual Enterprise, Canada, pp. 627-634.

Smith, A. and Rupp, W. 2002. Communication and loyalty among knowledge workers: a resource 
of the firm theory view. Journal of Knowledge Management, 6(3), pp. 250-261.

Smith, E.A. 2001. The role of tacit and explicit knowledge in the workplace. Journal of Knowledge Management, 5(4), pp. 311-321.

Suppiah, V. and Sandhu, M.S. 2011. Organizational culture's influence on tacit knowledge-sharing behaviour. Journal of Knowledge Management, 15, (3), pp. 462-477.

Taghizadeh, H. 2015. Investigation the effect of knowledge management on organizational agility. Shiraz Journal of System Management, 3(1), Ser. 9, pp. 67-86.

Teng, S.M. 2010. The correlation between organizational culture and knowledge conversion on corporate performance. Journal of Knowledge Management, 14(2), pp. 269284.

Thompson, J. 1967. Organization in Action. New York, NY.: McGraw-Hill.

Turban, E., McLean, E., and Wetherbe, J. 2003. Information technology for management: transforming organizations in the digital economy. New York: John Wiley \& Sons.

Van den Hooff, B. and de Ridder, J.A. 2004. Knowledge sharing in context: the influence of organizational commitment, communication climate and CMC use on knowledge sharing. Journal of Knowledge Management, 8(6), pp. 117-130.

Van den Hooff, B. and Van Weenen, F.D.L. 2004. Committed to share: commitment and CMC use as antecedents of knowledge sharing. Knowledge and Process Management, 11(1), pp. 13-24.

Wang, C.C. and Yang, Y.J. 2007. Personality and intention to share knowledge: an empirical studiy of scientists in and R\& D laboratory. Social
Behavior and Personality, 35(10), pp. 14271436.

Wang, C.L. and Ahmed, P.K. 2003. Structure \& Structural Dimensions for Knowledge-Based Organizations. Measuring Business Excellence, 7(1), pp. 51-62.

Weggeman, M. 2000. Knowledge management: practice. Schiedam: Scriptum Management.

Yaghoubi, N.M. and Dahmardeh, M.R. 2011. Knowledge management: critical success factor in organizational agility. American Journal of Social and Management Sciences, 2(3), pp. 272-277.

Yang, C.C. 2015. The integrated model of core competence and core capability. Total Quality Management \& Business Excellence, Vol. 26, pp. 1-17.

Yazdani, A. and Salarzahi, H. 2014. Investigate the relationship between dimensions of organizational culture (based on Denison model) with organizational agility capabilities in Civil Registration in Sistan and Baluchestan. Journal of Novel Applied Sciences, 3(2), pp. 1654-1660.

Yeganegi, K. and Azar, M.S.Z. 2012. The effect of IT on organizational agility. Proceedings of the 2012 International Conference on Industrial Engineering and Operations Management, Istanbul, Turkey, July 3-6.

$\mathrm{Yu}, \mathrm{T}$. and $\mathrm{Wu}, \mathrm{N}$. 2009. A review of study on the competing values framework. International Journal of Business and Management, 4(7), pp. 37-42.

Zhang, Z. and Sharifi, H. 2000. A methodology for achieving agility in manufacturing organizations. International Journal of Operations \& Production Management, 20(4), pp. 496-512. 